Old Dominion University

ODU Digital Commons

Physics Faculty Publications

Physics

2019

Question 1: Cost to Carpool; Question 2: Waiting in TSA Lines

Larry Weinstein

Old Dominion University, Iweinste@odu.edu

Follow this and additional works at: https://digitalcommons.odu.edu/physics_fac_pubs

Part of the Physics Commons

Original Publication Citation

Weinstein, L. (2019). Question 1: Cost to carpool; Question 2: Waiting in TSA lines. Physics Teacher, 57(7), 501. doi:10.1119/1.5126839

This Article is brought to you for free and open access by the Physics at ODU Digital Commons. It has been accepted for inclusion in Physics Faculty Publications by an authorized administrator of ODU Digital Commons. For more information, please contact digitalcommons@odu.edu. 


\section{Question 1: Cost to carpool; Question 2: Waiting in TSA lines}

Larry Weinstein

Citation: The Physics Teacher 57, 501 (2019); doi: 10.1119/1.5126839

View online: https://doi.org/10.1119/1.5126839

View Table of Contents: https://aapt.scitation.org/toc/pte/57/7

Published by the American Association of Physics Teachers

\section{ARTICLES YOU MAY BE INTERESTED IN}

Entropy as Disorder: History of a Misconception

The Physics Teacher 57, 454 (2019); https://doi.org/10.1119/1.5126822

Solutions for Fermi Questions, October 2019: Question 1: Cost to carpool; Question 2: Waiting in TSA lines The Physics Teacher 57, A501 (2019); https://doi.org/10.1119/1.5126813

Up and away ...

The Physics Teacher 57, 501 (2019); https://doi.org/10.1119/1.5126838

Robert A. Millikan and the Oil Drop Experiment

The Physics Teacher 57, 442 (2019); https://doi.org/10.1119/1.5126819

Rocket Propulsion, Classical Relativity, and the Oberth Effect

The Physics Teacher 57, 439 (2019); https://doi.org/10.1119/1.5126818

ACCELERATING NELLIE

The Physics Teacher 57, 438 (2019); https://doi.org/10.1119/1.5126817 


\section{Physics Challenge for Teachers and Students}

Boris Korsunsky, Column Editor Weston High School, Weston, MA 02493

challenges@aapt.org

\section{Up and away ...}

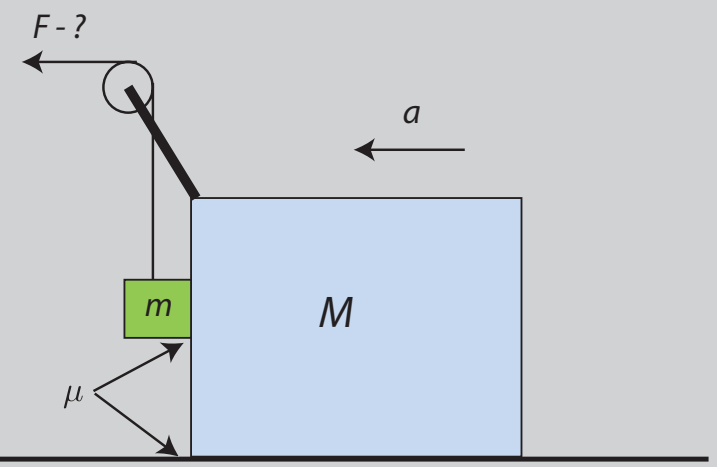

A block of mass $M$ is placed on a horizontal floor. A frictionless pulley is attached to the top edge of the block, and a light string passes over the pulley as shown. A cube of mass $m$ is suspended from the string so that the bottom part of the string is vertical, and the cube touches the block. The coefficient of kinetic friction between the block and the cube as well as between the block and the floor is $\mu$.

The string is pulled horizontally by a force of unknown magnitude $F$. As a result, the cube slides upward, and the block is moving with acceleration $a$. Find $F$.

\section{Guidelines for contributors}

- We ask that all solutions, preferably in Word format, be submitted to the dedicated email address challenges@aapt.org.Each message will receive an automatic acknowledgment.

- If your name is-for instance-Makoto Kobayashi, please name the file "Kobayashi190ct" (do not include your first initial) when submitting the October 2019 solution.

- The subject line of each message should be the same as the name of the solution file.

- The deadline for submitting the solutions is the last day of the corresponding month.

- Each month, a representative selection of the successful solvers' names will be published in print and on the web.

- If you have a message for the Column Editor, you may contact him atkorsunbo@post.harvard.edu; however, please do not send your solutions to this address.

Many thanks to all contributors and we hope to hear from many more of you in the future!

Note: as always, we would very much appreciate reader-contributed original Challenges.

Boris Korsunsky, Column Editor

DOI: $10.1119 / 1.5126838$

\section{Fermi Questions}

Larry Weinstein, Column Editor Old Dominion University, Norfolk, VA 23529; weinstein@odu.edu

\section{Duestion 1: Cost to carpool}

How much extra gasoline does it cost to carpool, i.e., to carry another passenger?

\section{Question 2: Waiting in TSA lines}

How much time is spent each year in the U.S. waiting in security lines at airports?

Look for the answers online at tpt.aapt.org under "Browse," at the very end of the current issue.

Question suggestions are always welcome!

For more Fermi questions and answers, see Guesstimation 2.0: Solving Today's Problems on the Back of a Napkin, by Lawrence Weinstein (Princeton University Press, 2012). 